\title{
Common Information in Carry Trade Risk Factors
}

\author{
Joseph P. Byrne, Boulis Maher Ibrahim, and Ryuta Sakemoto*
}

October 14th 2016

\begin{abstract}
Carry returns have been widely observed in the FX market. This study exploits the common information embedded in several factors previously identified as relevant to carry trade returns. We find that the extracted common factor successfully models the time series and cross-sectional characteristics of carry returns. Empirical evidence is presented that the common factor produces smaller pricing errors than other well known factors, such as innovations of exchange rate volatility and the downside stock market excess return. Our results also suggest that stock market risk is somewhat segmented from FX market risk. JEL Classification Codes: C38, F31, G12, G15
\end{abstract}

Keywords: Currency Carry Trade, Risk Factor, Principal Components, Fama-MacBeth

*Byrne (corresponding author), J.P.Byrne@hw.ac.uk, Ibrahim, B.M.Ibrahim@hw.ac.uk, and Sakemoto, rs7@hw.ac.uk, Department of Accountancy, Economics and Finance, Heriot-Watt University, Edinburgh, EH14 4AS, United Kingdom. 


\section{Introduction}

The carry trade is an investment strategy that involves borrowing in a low interest rate currency and investing in a high interest rate currency. Applying this strategy to many currencies allows for the building of currency portfolios and the diversification of some market risk, as proposed by Lustig and Verdelhan (2007). They focus on cross-sectional interest rate differentials and show that a high interest rate currency portfolio yields a higher average return than a low interest rate currency portfolio. In seeking to extend Lustig and Verdelhan (2007), several risk factors have been proposed in the carry trade literature. These can be generically categorized into currency and non-currency factors. Currency factors exploit readily available foreign exchange market information. For example, Lustig et al. (2011) propose the return difference between high and low interest rate currency portfolios, and Menkhoff et al. (2012a) suggest innovations of global foreign exchange volatility as currency factors. Non-currency factors exploit macro or finance information. For instance, Lustig and Verdelhan (2007) use U.S. durable and nondurable consumption growth, based on the Consumption CAPM. Atanasov and Nitschca (2014), Dobrynskaya (2014), and Lettau et al. (2014) investigate downside stock market risk for the FX market. Although most studies explore either currency or non-currency risk factors, these factors may be related to each other, since many institutional investors invest across assets. We propose to test the incremental benefit of combining the information embedded in both currency and non-currency factors previously identified in the literature.

It can be argued that common risk information is important from both a theoretical and an empirical perspective. Lustig et al. (2011) propose a no-arbitrage model which has common and country-specific factors. Heterogeneity across currencies in the exposure to the common factor is substantial, and is relevant for positive carry trade returns. In their model, the country specific factors are averaged out in each portfolio, therefore the common factor plays an important role. From an empirical perspective, common risk factors 
have been identified when modelling excess returns in the bond market (see Ludvigson and $\mathrm{Ng}, 2009)$. The common information across exchange rates are explored by Engel et al. (2015). They find that the common factor extracted from exchange rates themselves includes information that is not extracted from macroeconomic fundamentals. Giglio et al. (2016) construct an index to capture the common component in some systemic risk measures. They present empirical evidence that the common index can predict macroeconomic shocks more accurately than a large cross-section of risk measures can do individually. The high minus low interest rate currency portfolios factor $\left(H M L_{F X}\right)$ proposed by Lustig et al. (2011) prices cross-sectional carry returns. However, this factor uses information from only two portfolios of currencies. If a common factor is important for carry trades, this factor may be enhanced by adding information embedded in the other factors.

Our approach contributes in the following ways. First, we are able to identify common information in currency and non-currency risk factors for carry trades. This allows us to test whether adding non-currency information to currency information help us to better price carry portfolios. This is important since Lettau et al. (2014) find that stock market risk is common between currency carry trades and other assets. Our approach allows us to consider financial and macro risk more generally, since we examine the overlap between currency and non-currency risk, and the latter includes stock market risk. Second, our approach reduces dimensionality in a large cross-section of risk factors. Although the FX portfolio approach averages out the impact of outliers, the number of currency portfolios used in the literature reduces the degrees of freedom, and hence the ability to consider several factors simultaneously. Our approach avoids this difficulty by using a single common factor. Finally, our empirical approach is free from potential multicollinearity problems. One risk factor may be correlated with others, and hence multicollinearity may affect the estimation results. Our approach allows us to extract the common factor even when the number of risk factors increases.

The empirical results show that the extracted common factor can price currency portfo- 
lios in both time series and cross-sectional contexts. In the cross-section, relevant tests fail to reject the null hypothesis that there is no pricing error. In addition, the model exhibits a high $R^{2}$ and low root mean squared error. We also consider the incremental usefulness of the common factor using an orthogonalization that identifies the factor's marginal information. Evidence is presented that the common factor has additional explanatory power compared with global FX volatility innovations and downside world stock market risk. This common factor is strongly related to the high interest rate currency portfolio. These results are also robust to transaction costs.

The rest of this paper is organized as follows: Section 2 reviews the related carry trade literature, Section 3 describes our methodology and the dataset, Section 4 presents a discussion of our empirical results, Section 5 sets out robustness tests of key results, and Section 6 concludes.

\section{Brief Literature Review}

Positive returns of currency carry trades are dependent upon systematic deviations from Uncovered Interest rate Parity (UIP) condition. UIP suggests a high interest rate country's currency depreciates against a low interest rate country's currency. This parity condition has been called into question by empirical evidence (see Fama, 1984; Lewis, 1995; and Engel, 1996). Most studies focus on bilateral currency relations, while Lustig and Verdelhan (2007) use a portfolio approach to sort currencies based on cross-sectional interest rate differences. The portfolio approach exploits diversification benefits and generates a higher Sharpe ratio than those of individual currencies or the U.S. stock market (see Burnside et al., 2011). Das et al. (2013) indicate that carry trades have different characteristics from international stocks, U.S. bonds, real estates, and commodities. The carry trade portfolio is used by Das et al. (2013) as the new asset class to enhance the entire portfolio performance.

High profitability of currency carry trades depends upon market states, such as market volatility, and liquidity. The most widely used state variable is FX market volatility. For 
instance, Christiansen et al. (2011) adopt a smooth transition regression model with factor betas are governed by FX volatility. They show that carry trades have high exposure to the stock market when FX volatility is high. Copeland and Lu (2016) find that most profits of carry trades are attributed to low FX volatility periods. They propose an enhanced trading strategy which adopts carry during low FX volatility periods and real exchange rate deviation during high FX volatility periods. Using the component GARCH model, Ahmed and Valente (2015) decompose Menkhoff et al.'s (2012a) global FX volatility into short-run and long-run components and show that the long-run component has a risk premium. They find this long-run component related to U.S. macro fundamentals. Dos Santos et al. (2016) also focus on short-run and long-run components and investigate their risk premium for each emerging currency. They model the residuals of the UIP regression by the component GARCH-M model. They present evidence that the short-run component is related to speculative pressures, whereas the long-run component is associated with macro fundamentals. Market liquidity is also important for carry trades. It is argued by Brunnermeier et al. (2009) that carry trades have crash risk when speculators are subjected to funding constraints. They use the TED spread to measure funding constraints, and show that it predicts future returns of carry trades. Orlov (2016) compares liquidity in the stock market with that in the exchange rate market and shows that the latter is the dominant factor in determining carry returns. Although these studies highlight the pricing relevance to the cross-section of currency portfolios of specific types of information, the common component across these types has not been properly examined.

\section{Methodology and Data}

\subsection{Estimation Procedure}

To identify the risk price of our common factor for carry returns, we use the Fama and MacBeth (1973) two-step approach. First, the excess carry return, $r_{j, t}$, of currency portfolio 
$j$ at time $t$, can be explained by a risk factor $h_{t}$. The first stage Fama-MacBeth time series regression is used to determine the beta $\left(\beta_{j}\right)$ associated with this factor for each portfolio:

$$
r_{j, t}=\alpha_{j}+\beta_{j} h_{t}+e_{j, t}
$$

Central to our analysis, the risk price, $\lambda$, is obtained by a second cross-sectional regression of the portfolios' time series average excess returns $E\left[r_{j}\right]$ on the estimated betas $\hat{\beta}_{j}$ :

$$
E\left[r_{j}\right]=\lambda \hat{\beta}_{j}+e r_{j}
$$

where $e r_{j}$ is a cross-sectional error term. Since these betas are estimated values, estimation uncertainty should be taken into account in statistical inference. Accordingly, we employ the Shanken (1992) standard errors to account for estimation uncertainty. Burnside (2011) also adopts the Shanken approach. These standard errors add an adjustment for the effect of the variance-covariance matrix of the factor.

The common information across currency and non-currency factors is extracted by principal components. Define $\mathbf{X}$ to be the $T \times N$ standardized risk factors matrix with elements, $x_{i, t}, i=1, \ldots, N, t=1, \ldots, T$. We use nine risk factors and hence $N=9$. Each risk factor, $x_{i, t}$, is decomposed into a common factor, $f_{t}$, and an idiosyncratic component, $\epsilon_{i, t}$, as:

$$
x_{i, t}=\Lambda_{i} f_{t}+\epsilon_{i, t}
$$

where $\Lambda_{i}$ is the loading on the common factor.

We construct a factor mimicking portfolio, $F_{t}$. The factor mimicking portfolio allows us to represent the factor information as a traded asset. This also helps in comparisons of the explanatory power of factors, especially that some of the factors that we consider (explained below) are traded assets while others are not. This is carried out to take account of Menkhoff et al.'s (2012a) observation that the difference between traded and non-traded 
assets may affect empirical results of the performance of portfolio strategies. Accordingly, the factor mimicking portfolio is used. This is obtained by the following two steps. First, we regress our common factor $f_{t}$ onto six carry trade portfolio returns $\mathbf{R}_{\mathbf{t}}$ :

$$
f_{t}=a+b^{\prime} \mathbf{R}_{\mathbf{t}}+\eta_{t}
$$

where the parameter $a$ is a constant and $\eta_{t}$ is the error term. Next, using the estimated $b$ and the return vector, as $\hat{F}_{t}=\hat{b}^{\prime} \mathbf{R}_{\mathbf{t}}$, we obtain the factor mimicking portfolio $\hat{F}_{t}$. We replace the risk factor $h_{t}$ in Equation (1) by the mimicking portfolio $\hat{F}_{t}$.

\subsection{Carry Risk Factors}

We now set out nine carry trade risk factors prominently used in the recent literature. The first four risk factors are currency based and are denoted with subscripts FX, while the other five factors are non-currency based. We also utilise the average U.S. dollar $(D O L)$ factor, which is standard in the literature, and we typically include it in all specifications. ${ }^{1}$

1. $H M L_{F X, t}$ is the high minus low currency portfolio return mentioned in Lustig et al. (2011). It is the return spread between the highest interest rate portfolio (P6) and the lowest interest rate portfolio $(\mathrm{P} 1)$.

2. $\triangle V O L_{F X, t}$ is the global $\mathrm{FX}$ volatility innovations. We use the following two steps as in Meknhoff et al. (2012a) to calculate this variable. Let the daily log return of currency $j$ on day $\tau$ be $r_{j, \tau}=s_{j, \tau}-s_{j, \tau-1}$, where $s_{j, \tau}$ is the $\log$ of the spot exchange rate on day $\tau$. First, we estimate global FX volatility, $\sigma_{F X, t}$, in month $t$ as:

$$
\sigma_{F X, t}=\frac{1}{T_{t}} \sum_{\tau=1}^{T_{t}} \sum_{j=1}^{K_{\tau}}\left(\frac{\left|r_{j, \tau}\right|}{K_{\tau}}\right)
$$

where $\left|r_{j, \tau}\right|$ is the absolute value of $r_{j, \tau}, K_{\tau}$ is the number of currencies on day $\tau$, and $T_{t}$ is

\footnotetext{
${ }^{1} D O L$ is computed as the average of all currency excess returns.
} 
the total number of trading days in month $t$. We then estimate volatility innovations as the residuals of a $\mathrm{AR}(1)$ process for $\sigma_{F X, t}$.

3. $S K E W_{F X, t}$ is the global FX skewness proposed by Rafferty (2011). First, we calculate month $t$ skewness of currency $j, S K E W_{j, t}$.

$$
S K E W_{j, t}=\frac{1 / T_{t} \sum_{\tau=1}^{T_{t}}\left(r_{j, \tau}-\bar{r}_{j}\right)^{3}}{\left[1 / T_{t} \sum_{\tau=1}^{T_{t}}\left(r_{j, \tau}-\bar{r}_{j}\right)^{2}\right]^{3 / 2}}
$$

where $\bar{r}_{j}$ is the sample average of $r_{j, \tau}$ within month $t$. Since negative skewness is bad (good) for investing (funding) in a currency, we adjust the sign of the skewness based on the forward discount of currency $j$ at the end of month $t-1, f w_{j, t-1}-s_{j, t-1}$, where $f w_{j, t-1}\left(s_{j, t-1}\right)$ is the $\log$ of the forward (spot) exchange rate of currency $j$. The global FX skewness is calculated by:

$$
S K E W_{F X, t}=\frac{1}{K_{t}} \sum_{j=1}^{K_{t}} \operatorname{sign}\left(f w_{j, t-1}-s_{j, t-1}\right) S K E W_{j, t}
$$

We also use the innovation part of $S K E W_{F X, t}$, but this has no qualitative effect on the results, as shown in the robustness section.

4. $\Delta L V O L_{F X, t}$ is the long-run global FX volatility innovations. ${ }^{2}$ Ahmed and Valente (2015) estimate long-run volatility from the global FX market using the component GARCH model proposed in Engel and Lee (1999). The conditional variance of average daily currency

\footnotetext{
${ }^{2}$ Ahmed and Valente (2015) report that the long-run component is important pricing currency carry portfolios. Including the short-run part does not affect our common factor. See the Online Appendix.
} 
return $\bar{r}_{\tau}$ is decomposed into short-run and long-run components as:

$$
\begin{array}{r}
\bar{r}_{\tau}=\psi_{1}+u_{\tau}, u_{\tau}=\sigma_{\tau} \eta_{\tau}, \eta_{\tau} \sim i . i . d . N(0,1) \\
\sigma_{\tau}^{2}-q_{\tau}=\psi_{2}\left(u_{\tau-1}^{2}-q_{\tau-1}\right)+\psi_{3}\left(u_{\tau-1}^{2}-q_{\tau-1}\right) d_{\tau-1}+\psi_{4}\left(\sigma_{\tau-1}^{2}-q_{\tau-1}\right) \\
q_{\tau}=\psi_{5}+\psi_{6}\left(q_{\tau-1}-\psi_{5}\right)+\psi_{7}\left(u_{\tau-1}^{2}-\sigma_{\tau-1}^{2}\right)
\end{array}
$$

where $\sigma_{\tau}^{2}-q_{\tau}$ is the short-run component and $q_{\tau}$ is the long-run component of the conditional volatility $\sigma_{\tau}$. We use daily series for estimation and pick up the end of month values to construct the monthly series (see Ahmed and Valente, 2015). We take the first difference of the monthly series to extract innovations.

5. $\triangle T E D_{t}$ is the TED spread innovations. The TED spread is the difference between the three month Eurodollar LIBOR rate and the three month Treasury bill rate. ${ }^{3}$ This value reflects banks' funding constrains. Brunnermeier et al. (2009) show that the TED spread helps to predict future carry trade returns. We extract the innovation component as the first difference.

6. $W m k t_{t}$ is the global stock market excess return which we approximate by the MSCI world index return (U.S. dollar base). The one month Treasury Bill rate is used as the risk free rate and is subtracted from the world index return.

7. $D W m k t_{t}$ denotes the downside global stock market excess return which is computed using a dummy variable, that is equal to 1 if the world stock market excess return is negative, and zero otherwise. ${ }^{4}$ We slightly change the definition of Dobrynskaya (2014) to highlight

\footnotetext{
${ }^{3}$ Instead of the three month LIBOR, we use the three month interbank rate in the U.S. to cover a longer period.

${ }^{4}$ Downside risk has also been considered by Farhi and Gabaix (2016).
} 
downside information as follows: ${ }^{5}$

$$
D W m k t_{t}=d u m m y \times W m k t_{t} .
$$

8. and 9. $\Delta N C_{t}$ and $\Delta C_{t}$ are nondurable and durable consumption growth. We use monthly growth rates in real per capita nondurables and durables consumption, which is adopted by Kan et al. (2013). We employ personal durable and nondurable consumption expenditure data and adjust them using the consumer price index (durable and nondurable goods) and total population. ${ }^{6}$

We first present premia facia evidence that these risk factors are correlated using Pearson correlation coefficients (See the Online Appendix). This supports our major contention that there is common information in the carry trade factors and spill-overs between currency and non-currency risks.

We use 48 currencies over the period November 1983 through December 2013. The currencies are the same as those analyzed by Menkhoff et al. (2012a). As is standard in this literature, we construct six portfolios based on the forward discount at monthly frequency. The U.S. dollar is taken as the base currency, since we take the perspective of an U.S. investor. Following Lustig et al. (2011), we take trading costs into account in portfolio construction by using bid and ask prices when buying and selling currencies. Further, the data is pre-treated using the method of Darvas (2009) who adopts the previous day's observations when there is no difference between bid and ask prices, or the spread of the forward rates is smaller than that of the spot rates.

\footnotetext{
${ }^{5}$ Dobrynskaya (2014) uses the upside market dummy and it does not allow us to extract downside market information as a single variable.

${ }^{6}$ Consumption CAPM justifies utilising the risk associated with durable and nondurable consumption growth, for further details see Lustig and Verdelhan (2007).
} 


\section{Table 1 Asset Pricing Model}

\begin{tabular}{|c|c|c|c|c|c|}
\hline \multicolumn{6}{|c|}{ Panel A: Factor Betas } \\
\hline Portfolio & $\alpha$ & $D O L$ & $F$ & & $\operatorname{adj}-R^{2}$ \\
\hline $\mathrm{P} 1$ & $\begin{array}{r}0.05 \\
(0.04)\end{array}$ & $1.28^{* * *}$ & $-2.21^{* * *}$ & & 0.93 \\
\hline $\mathrm{P} 2$ & $\begin{array}{r}-0.09 \\
(0.05)\end{array}$ & $\begin{array}{l}1.12^{* * *} \\
(0.03)\end{array}$ & $\begin{array}{l}-1.12^{* * *} \\
(0.13)\end{array}$ & & 0.88 \\
\hline P3 & $\begin{array}{r}0.03 \\
(0.05)\end{array}$ & $\begin{array}{l}1.06^{\text {*** }} \\
(0.03)\end{array}$ & $\begin{array}{l}-0.50^{* * *} \\
(0.13)\end{array}$ & & 0.90 \\
\hline $\mathrm{P} 4$ & $\begin{array}{r}0.02 \\
(0.05)\end{array}$ & $\begin{array}{l}0.83^{* * *} \\
(0.03)\end{array}$ & $\begin{array}{l}0.91^{* * *} \\
(0.15)\end{array}$ & & 0.88 \\
\hline P5 & $\begin{array}{l}-0.06 \\
(0.05)\end{array}$ & $\begin{array}{c}0.97^{* * *} \\
(0.04)\end{array}$ & $\begin{array}{l}0.45^{* * *} \\
(0.15)\end{array}$ & & 0.85 \\
\hline P6 & $\begin{array}{r}0.04 \\
(0.05) \\
\end{array}$ & $\begin{array}{c}0.73^{* * *} \\
(0.04) \\
\end{array}$ & $\begin{array}{l}2.46^{* * *} \\
(0.17) \\
\end{array}$ & & 0.89 \\
\hline \multicolumn{6}{|c|}{ Panel B: Risk Prices } \\
\hline Risk Factor & (1) & (2) & (3) & (4) & (5) \\
\hline$D O L$ & $\begin{array}{r}0.18 \\
(0.12)\end{array}$ & $\begin{array}{r}0.18 \\
(0.12)\end{array}$ & $\begin{array}{r}0.18 \\
(0.12)\end{array}$ & $\begin{array}{r}0.18 \\
(0.12)\end{array}$ & $\begin{array}{r}0.18 \\
(0.12)\end{array}$ \\
\hline$F$ & $\begin{array}{l}0.12^{* * *} \\
(0.03)\end{array}$ & & & & \\
\hline$H M L_{F X}$ & & $\begin{array}{l}0.49^{* * *} \\
(0.12)\end{array}$ & & & \\
\hline$\Delta V O L_{F X}$ & & & $\begin{array}{l}-0.08^{* * *} \\
(0.02)\end{array}$ & & \\
\hline$W m k t$ & & & & $\begin{array}{l}0.40^{* * * *} \\
(0.12)\end{array}$ & \\
\hline$D W m k t$ & & & & & $\begin{array}{l}0.22^{* * *} \\
(0.06)\end{array}$ \\
\hline$R^{2}$ & 0.88 & 0.87 & 0.78 & 0.87 & 0.88 \\
\hline RMSE & 0.05 & 0.06 & 0.08 & 0.06 & 0.06 \\
\hline$\chi^{2}$ & 7.16 & $8.74^{*}$ & $10.89^{* *}$ & $8.75^{*}$ & 7.58 \\
\hline [p-value $]$ & {$[0.13]$} & {$[0.07]$} & {$[0.03]$} & {$[0.07]$} & {$[0.11]$} \\
\hline
\end{tabular}

Notes: This table displays asset pricing results from the Fama and MacBeth (1973) two pass procedure. Test assets are six all country currency portfolios. Panel A: Factor Betas provides time series regressions of excess returns of carry trade portfolios on a constant $(\alpha)$, and the common factor $(F)$ using Equation (1). The standard errors are reported in parentheses and obtained by the Newey and West (1987) procedure with optimal lag selection according to Andrews (1991). The adjusted $R^{2}$ is also reported. Panel B: Risk Prices presents cross-sectional pricing results of the linear factor model. The coefficient of factor risk premium $\lambda$ is estimated using Equation (2). A constant term is excluded in the cross-sectional model. $H M L_{F X}$ is the high minus low currency portfolios, $\triangle V O L_{F X}$ is the global FX volatility innovations, $W m k t$ is the world stock market excess return and $D W m k t$ is the downside world stock market excess return. Shanken (1992) standard errors are reported in parentheses $(\cdot)$. The $R^{2}$ is a measure of fit between the sample mean of excess return and the predicted mean return. The RMSE is the root of mean-squared error and is reported in percentage points. The $\chi^{2}$ test statistics of pricing errors are reported and the null hypothesis is that there is no pricing error. $p$-values are reported in square brackets[·]. Asterisk $* * *$, and $* * *$ indicate significance at the 10\%, 5\% and 1\% level, respectively. The sample period is from November 1983 to December 2013. 


\section{Empirical Results}

\subsection{Asset Pricing Model}

The main contribution of our approach is the enhanced modelling of both the time series and cross-sectional characteristics of carry trade portfolios. We control for the average U.S. dollar risk $(D O L)$ in all our regressions since this has been found to be important in capturing time series fluctuations of carry returns. First, we focus on Panel A in Table 1, which provides estimates of factor betas by the time series regressions of Equation (1). All factor betas on the common factor $F$ are statistically significant at the $1 \%$ level. They increase approximately monotonically from $\mathrm{P} 1$ to $\mathrm{P} 6$. This suggests that low interest rate currency portfolios act as a hedge against carry risk. None of the constant terms $\alpha$ are statistically significant, which implies that $D O L$ and $F$ successfully capture the time series fluctuations of currency portfolios. These results support the fact that our common factor models the time series behaviour of carry returns. We now consider the relative performance of time series standard risk factors. With reported insignificant betas or significant alphas, alternative risk factors prominent in the literature do not account for the time series behaviour of currency returns as successfully as our empirical factor, and we evidence this statement in the Online Appendix.

Panel B of Table 1 reports the cross-sectional asset pricing results. This is also important in assessing the performance of our common risk factor for carry returns. We run the crosssectional regression using Equation (2) but we do not include a constant term as proposed by Burnside (2011), since the constant term may affect the risk price estimation result. The results tabulated in Panel B column (1) shows that the risk price on the common factor is statistically significant at the $1 \%$ level. A $R^{2}$ of $88 \%$ indicates a very good model performance. Moreover, the results show that there is no significant pricing error for our empirical factor, since we are unable to reject the null hypothesis of pricing errors with the $\chi^{2}$ test in Table 1. For comparison purposes columns (2) to (5) present estimation results 
using other prominent factors in the carry trade literature. In these columns, $H M L_{F X}$ and FX market volatility innovations are currency factors, and the 'world stock market' and 'downside stock market' are non-currency factors. All four are computed by using mimicking-portfolios. Our cross-sectional model in column (1) is at least as good as any of the others in terms of a statistically significant risk price, a high $R^{2}$, and the pricing error test, whilst also having the smallest RMSE.

\subsection{Comparison with Other Risk Factors}

Having identified the usefulness of the common factor for carry returns, we next formally test whether our common factor can price cross-sectional carry trade portfolio returns better than the other factors individually. We focus on $H M L_{F X}$ and innovations in the global FX volatility as currency factors, and the downside world stock market excess return as a non-currency factor. We do not report the result of the stock market return since it is similar to that of the downside stock market return. ${ }^{7}$ Following Menkhoff et al. (2012a), we use an orthogonalization to avoid factor correlation and to identify which factor provides additional information. If the orthogonalized factor with respect to a comparative is statistically significant, this implies that there is incremental information not contained in the comparative factor.

Table 2 column (1) restates the results that our common factor is important for carry returns. This contrasts with columns (2), (3) and (4) which indicate that the other orthogonalized factors are not statistically significant when included with the common factor. These orthogonal risks are denoted by superscript Orth for $H M L_{F X}, \Delta V O L_{F X}$, and $D W m k t$. Hence, the remaining information in the standard factors does not contribute substantially to explaining carry returns. The common information in currency and non-currency factors is enough to explain the carry, and remaining risks elsewhere are less relevant. Columns (5), (6), and (7) of Table 2 show the results of the orthogonalized common factors. We investi-

\footnotetext{
${ }^{7}$ See the Online Appendix.
} 


\section{Table 2 Cross-sectional Returns and Orthogonalized Common Factor}

\begin{tabular}{|c|c|c|c|c|}
\hline Risk Factor & (1) & $(2)$ & (3) & (4) \\
\hline$D O L$ & 0.18 & 0.18 & 0.18 & 0.18 \\
\hline & $(0.12)$ & $(0.12)$ & $(0.12)$ & $(0.12)$ \\
\hline$F$ & $0.12^{* * *}$ & $0.12^{* * *}$ & $0.12^{* * *}$ & $0.12^{* * *}$ \\
\hline & $(0.03)$ & $(0.03)$ & $(0.03)$ & $(0.03)$ \\
\hline$H M L_{F X}^{O r t h}$ & & $\begin{array}{r}0.07 \\
(0.07)\end{array}$ & & \\
\hline$\Delta V O L_{F X}^{O r t h}$ & & & $\begin{array}{r}0.02 \\
(0.06)\end{array}$ & \\
\hline$D W m k t^{O r t h}$ & & & & $\begin{array}{r}-0.01 \\
(0.02)\end{array}$ \\
\hline$R^{2}$ & 0.88 & 0.89 & 0.94 & 0.90 \\
\hline RMSE & 0.05 & 0.05 & 0.04 & 0.05 \\
\hline$\chi^{2}$ & 7.16 & $7.16^{*}$ & 4.94 & $6.66^{*}$ \\
\hline$[p$-value $]$ & {$[0.13]$} & {$[0.07]$} & {$[0.18]$} & {$[0.08]$} \\
\hline Risk Factor & (5) & (6) & (7) & \\
\hline$\overline{D O L}$ & $\begin{array}{r}0.18 \\
(0.12)\end{array}$ & $\begin{array}{r}0.18 \\
(0.12)\end{array}$ & $\begin{array}{r}0.18 \\
(0.12)\end{array}$ & \\
\hline$H M L_{F X}$ & $\begin{array}{l}0.48^{* * *} \\
(0.12)\end{array}$ & & & \\
\hline$\Delta V O L_{F X}$ & & $\begin{array}{l}-0.08^{* * *} \\
(0.02)\end{array}$ & & \\
\hline$D W m k t$ & & & $\begin{array}{c}0.20^{* * *} \\
(0.05)\end{array}$ & \\
\hline$F^{\text {Orth }}$ & $\begin{array}{r}0.02 \\
(0.02)\end{array}$ & $\begin{array}{c}0.02^{*} \\
(0.01)\end{array}$ & $\begin{array}{l}0.03^{* *} \\
(0.01)\end{array}$ & \\
\hline$R^{2}$ & 0.89 & 0.94 & 0.90 & \\
\hline RMSE & 0.05 & 0.04 & 0.05 & \\
\hline$\chi^{2}$ & $7.16^{*}$ & 4.94 & $6.68^{*}$ & \\
\hline$[p$-value $]$ & {$[0.07]$} & {$[0.18]$} & {$[0.08]$} & \\
\hline
\end{tabular}

Notes: This table presents comparison results between the common factor $F$ and other factors. Orth indicates the factor is orthogonalized with respect to the comparative factor. These cross-section regression results are estimated by Equation (2). $H M L_{F X}$ is the high minus low currency portfolios, $\triangle V O L_{F X}$ is the global FX volatility innovations, and $D W m k t$ is the downside world stock market excess return. Shanken (1992) standard error are reported in parentheses $(\cdot)$. The $R^{2}$ is a measure of fit between the sample mean of excess return and the predicted mean return. The RMSE is the root of mean-squared error and is reported in percentage points. The $\chi^{2}$ test statistics of pricing errors are reported and the null hypothesis is that there is no pricing error. $p$-values are reported in square brackets [.]. Asterisk ${ }^{*}, * *$, and ${ }^{* * *}$ indicate significance at the $10 \%, 5 \%$, and $1 \%$ level, respectively. 
gate whether the remaining information in the common factor price cross-sectional currency portfolios. While column (5) does not indicate which factor dominates, taken together with the RMSE and pricing error results in Table 1, we can conclude that the common factor is superior to $H M L_{F X}$. Another advantage of our approach is that the common factor exploits more diversified information. In contrast, $H M L_{F X}$ extracts information only from the high and low interest rate currency portfolios, and, as will be discussed in the next section, this is more sensitive to the choice of currencies. Table 2 columns (6) and (7) show that the orthogonalized common factors $F^{O r t h}$ are statistically significant, which indicates that the common factor contains information not captured by $\triangle V O L_{F X}$ and $D W m k t$ on their own. This is particularly clear in column (7) since $F^{\text {Orth }}$ is statistically significant at the $5 \%$ level. The implication is that downside stock market information is insufficient in explaining currency carry returns and risks important for the carry trade are more prevalent than those that originate in the stock market.

\subsection{Developed Country Sample}

Currencies of some emerging countries may be less liquid than those of developed countries, and this may affect the results. We investigate this by considering a subsample of 15 developed countries to represent 'liquid' currencies. The 15 currencies are the same as those included in the dataset of Lustig et al. (2011). Table 3 presents the time series and cross-sectional results for these countries. From Panel A, four of the five betas on the common factor are statistically significant, and increase monotonically from P1 to P5. Panel B presents the cross-sectional results. Although the $R^{2}$ is not the best across the five models, the risk price on the common factor is statistically significant at the $1 \%$ level. In contrast, $H M L_{F X}$, which is the second best model in Table 2, is statistically significant at only the $5 \%$ level, and the $R^{2}$ is the smallest. This result implies that our factor contains diversified information and, hence, it is more robust to against a sample of currencies. 


\section{Table 3 Asset Pricing in Developed Countries}

\begin{tabular}{|c|c|c|c|c|c|}
\hline \multicolumn{6}{|c|}{ Panel A: Factor Betas } \\
\hline Portfolio & $\alpha$ & $D O L$ & $F$ & & adj- $R^{2}$ \\
\hline $\mathrm{P} 1$ & $\begin{array}{l}0.12^{\text {*** }} \\
(0.04)\end{array}$ & $\begin{array}{l}1.31^{* * * *} \\
(0.02)\end{array}$ & $\begin{array}{l}-2.96^{* * *} \\
(0.10)\end{array}$ & & 0.94 \\
\hline P2 & $\begin{array}{l}-0.14^{* *} \\
(0.06)\end{array}$ & $\begin{array}{l}1.07^{* * *} \\
(0.04)\end{array}$ & $\begin{array}{l}-0.67^{* *} \\
(0.15)\end{array}$ & & 0.83 \\
\hline P3 & $\begin{array}{r}-0.06 \\
(0.05)\end{array}$ & $\begin{array}{l}1.01^{* * * *} \\
(0.02)\end{array}$ & $\begin{array}{r}0.04 \\
(0.15)\end{array}$ & & 0.89 \\
\hline $\mathrm{P} 4$ & $\begin{array}{l}-0.01 \\
(0.05)\end{array}$ & $\begin{array}{l}0.78^{* * *} \\
(0.03)\end{array}$ & $\begin{array}{l}1.50^{* * *} \\
(0.12)\end{array}$ & & 0.87 \\
\hline P5 & $\begin{array}{c}0.09^{* *} \\
(0.05) \\
\end{array}$ & $\begin{array}{l}0.83^{* * *} \\
(0.02)\end{array}$ & $\begin{array}{l}2.09^{* * *} \\
(0.12)\end{array}$ & & 0.94 \\
\hline \multicolumn{6}{|c|}{ Panel B: Risk Prices } \\
\hline Risk Factors & $(1)$ & $(2)$ & $(3)$ & $(4)$ & $(5)$ \\
\hline$D O L$ & $\begin{array}{r}0.19 \\
(0.13)\end{array}$ & $\begin{array}{r}0.19 \\
(0.13)\end{array}$ & $\begin{array}{r}0.19 \\
(0.13)\end{array}$ & $\begin{array}{r}0.19 \\
(0.13)\end{array}$ & $\begin{array}{r}0.19 \\
(0.13)\end{array}$ \\
\hline$F$ & $\begin{array}{l}0.09^{* * *} \\
(0.03)\end{array}$ & & & & \\
\hline$H M L_{F X}$ & & $\begin{array}{c}0.33^{* *} \\
(0.14)\end{array}$ & & & \\
\hline$\triangle V O L_{F X}$ & & & $\begin{array}{l}-0.06^{* * *} \\
(0.02)\end{array}$ & & \\
\hline$W m k t$ & & & & $\begin{array}{l}0.31^{* * *} \\
(0.11)\end{array}$ & \\
\hline$D W m k t$ & & & & & $\begin{array}{l}0.16^{\text {*** }} \\
(0.06)\end{array}$ \\
\hline$R^{2}$ & 0.60 & 0.53 & 0.59 & 0.76 & 0.68 \\
\hline RMSE & 0.09 & 0.10 & 0.10 & 0.07 & 0.09 \\
\hline$\chi^{2}$ & $8.23^{* *}$ & $9.82^{* *}$ & $9.03^{* *}$ & 5.03 & $6.40^{*}$ \\
\hline$[p$-value $]$ & {$[0.04]$} & {$[0.02]$} & {$[0.03]$} & {$[0.17]$} & {$[0.09]$} \\
\hline
\end{tabular}

Notes: This table displays asset pricing results from the Fama and MacBeth (1973) two pass procedure. Test assets are five developed country currency portfolios. Panel A: Factor Betas provides time series regressions of excess returns of carry trade portfolios on a constant $(\alpha)$, and the common factor $(F)$ using Equation (1). The standard errors are reported in parentheses and obtained by the Newey and West (1987) procedure with optimal lag selection according to Andrews (1991). The adjusted $R^{2}$ is also reported. Panel B: Risk Prices presents cross-sectional pricing results of the linear factor model. The coefficient of factor risk premium $\lambda$ is estimated using Equation (2). A constant term is excluded in the cross-sectional model. $H M L_{F X}$ is the high minus low currency portfolios, $\triangle V O L_{F X}$ is the global FX volatility innovations, $W m k t$ is the world stock market excess return and $D W m k t$ is the downside world stock market excess return. Shanken (1992) standard errors are reported in parentheses $(\cdot)$. The $R^{2}$ is a measure of fit between the sample mean of excess return and the predicted mean return. The RMSE is the root of mean-squared error and is reported in percentage points. The $\chi^{2}$ test statistics of pricing errors are reported and the null hypothesis is that there is no pricing error. $p$-values are reported in square brackets [.]. Asterisk $*, * *$, and $* * *$ indicate significance at the 10\%, 5\% and 1\% levels, respectively. The sample period is from November 1983 to December 2013. 


\section{Table 4 Marginal $R^{2}$ of All Risk Factors}

\begin{tabular}{lcc}
\hline Risk Factor & All countries & Developed countries \\
\hline$H M L_{F X}$ & 0.20 & 0.24 \\
$\Delta V O L_{F X}$ & 0.55 & 0.54 \\
$S K E W_{F X}$ & 0.03 & 0.04 \\
$\Delta L V O L_{F X}$ & 0.48 & 0.50 \\
$\Delta T E D$ & 0.17 & 0.18 \\
$W m k t$ & 0.56 & 0.57 \\
$D W m k t$ & 0.60 & 0.62 \\
$\Delta C$ & 0.00 & 0.01 \\
$\Delta N C$ & 0.00 & 0.01 \\
\hline
\end{tabular}

Notes: The table shows the $R^{2}$ from regressing individual data series onto the common factor, following Ludvigson and $\mathrm{Ng}$ (2009). $H M L_{F X}$ is the high minus low currency portfolio return, $\triangle V O L_{F X}$ is the global FX volatility innovations, $S K E W_{F X}$ is the global FX skewness, $\triangle L V O L_{F X}$ is the long-run global FX volatility innovations, $\triangle T E D$ is the TED spread innovations, $W m k t$ is the global stock market excess return, $D W m k t$ is the downside global stock market excess return, $\Delta C$ is the durable consumption growth, and $\triangle N C$ is the nondurable consumption growth.

\subsection{Interpretation of the Factor}

Our earlier empirical results show that our approach does well in extracting information relevant to the asset pricing model. Although the common factor is related to all risk factors, it is unlikely that the link is the same for every factor. We, therefore, examine the relationship to each separate risk factor as we interpret the common factor. Following Ludvigson and $\mathrm{Ng}$ (2009) in modelling bond markets, the marginal $R^{2}$ is calculated by regressing each risk factor on the common factor. Table 4 presents the results of the Marginal $R^{2}$. We observe the FX market volatility and the stock market are strongly related to the common factors, since their marginal $R^{2}$ is greater than 0.5. In contrast, $H M L_{F X}$, which is computed from currency portfolio returns, is less strongly linked to the common factor compared with volatility and the stock market. Although both $F$ and $H M L_{F X}$ have a good fit in Table 1, they provide different information. These results also show that our common factor does not load on to a specific factor and the information it carries is diversified across risk factors. In addition, these results are similar between all and developed countries. This fact supports the earlier discussion that our approach is more robust to the choice of the 
countries. It is also interesting to note that the marginal $R^{2}$ of the consumption factors are almost zero. This is mostly due to the fact that monthly consumption data is very noisy, as pointed out by Brandt et al. (2006).

\section{Table 5 Beta Sorted Portfolios}

\begin{tabular}{|c|c|c|c|c|c|c|c|}
\hline \multicolumn{8}{|c|}{ Panel A: All countries } \\
\hline & P1 & P2 & P3 & $\mathrm{P} 4$ & P5 & P6 & P6-P1 \\
\hline \multirow[t]{2}{*}{ mean } & 0.63 & 1.65 & 2.41 & 3.11 & 2.76 & $6.17^{* *}$ & $5.54^{* * *}$ \\
\hline & {$[0.48]$} & {$[1.00]$} & {$[1.34]$} & {$[1.64]$} & {$[1.40]$} & {$[2.50]$} & {$[2.63]$} \\
\hline & 6.01 & 7.52 & 8.99 & 9.43 & 9.76 & 10.74 & 9.95 \\
\hline \multicolumn{8}{|c|}{ Panel B: Developed countries } \\
\hline & $\mathrm{P} 1$ & $\mathrm{P} 2$ & P3 & $\mathrm{P} 4$ & P5 & & $\mathrm{P} 5-\mathrm{P} 1$ \\
\hline \multirow[t]{2}{*}{ mean } & -0.29 & 1.02 & 1.78 & 3.18 & $5.55^{* * *}$ & & $5.84^{* * *}$ \\
\hline & {$[0.17]$} & {$[0.52]$} & {$[0.80]$} & {$[1.60]$} & {$[2.58]$} & & {$[2.90]$} \\
\hline std.dev & 9.01 & 9.75 & 10.40 & 9.95 & 10.83 & & 10.10 \\
\hline
\end{tabular}

Notes: This table reports annualized mean and annualized standard deviations for currency portfolios sorted by currency betas to the common factor. The betas are computed by a rolling time-series regression of individual currencies' excess returns on the common factor. The moving window size is 36 months. Newey and West (1987) HAC $t$-statistics are reported in squared brackets [.]. Asterisks *,**, and *** indicate significance at the $10 \%, 5 \%$ and $1 \%$ levels, respectively. The sample period is December 1986 to December 2013. There are only five portfolios for developed countries subsample, since there is a smaller number of currencies.

\subsection{Beta Sorted Portfolios}

If the common factor is a risk factor for currencies, currencies would have systematic factor exposure differences to this factor's risk. Hence, the beta sorted portfolios will also generate return differences across currency portfolios. To this end, we sort portfolios based on betas to a risk factor, instead of the forward discount. This is the approach adopted in Lustig et al. (2011) and Menkhoff et al. (2012a). To sort by betas we first estimate a factor beta by regressing each currency excess return on a constant and the common factor. We use a sample window of 36 months. After obtaining the currency factor beta in month $t-1$, we sort the currencies based on the factor betas and compute the currency excess return of portfolios in month $t$. Table 5 presents the results of portfolios sorted by the common factor betas. For the full sample of countries and for the subsample of developed countries, returns 
increase approximately monotonically from the first to the last portfolios. High exposure portfolios, which are P6 for all countries and P5 for developed countries, have statistically significant positive returns. More importantly, the return differences between the last and the first portfolios are statistically significant at the $1 \%$ level. This implies that the common factor bears systematic risk to currencies.

\section{Table 6 Asset Pricing Model: One Factor Model}

\begin{tabular}{|c|c|c|c|c|c|c|c|c|c|}
\hline \multicolumn{5}{|c|}{ All countries } & \multicolumn{5}{|c|}{ Developed countries } \\
\hline \multicolumn{10}{|c|}{ Panel A: Factor Betas } \\
\hline & $\alpha$ & $F$ & $\operatorname{adj}-R^{2}$ & & & $\alpha$ & $F$ & $\operatorname{adj}-R^{2}$ & \\
\hline \multirow[t]{2}{*}{ P1 } & -0.07 & $0.85^{* * *}$ & 0.03 & & P1 & 0.10 & -0.01 & 0.00 & \\
\hline & $(0.14)$ & $(0.31)$ & & & & $(0.16)$ & $(0.34)$ & & \\
\hline \multirow[t]{2}{*}{$\mathrm{P} 2$} & -0.19 & $1.58^{* * *}$ & 0.12 & & $\mathrm{P} 2$ & -0.15 & $1.73^{* * *}$ & 0.11 & \\
\hline & $(0.14)$ & $(0.30)$ & & & & $(0.15)$ & $(0.29)$ & & \\
\hline \multirow[t]{2}{*}{ P3 } & -0.07 & $2.05^{* * *}$ & 0.20 & & P3 & -0.08 & $2.30^{* * *}$ & 0.22 & \\
\hline & $(0.12)$ & $(0.28)$ & & & & $(0.14)$ & $(0.31)$ & & \\
\hline \multirow[t]{2}{*}{$\mathrm{P} 4$} & -0.06 & $2.91^{* * *}$ & 0.43 & & $\mathrm{P} 4$ & -0.02 & $3.25^{* * *}$ & 0.45 & \\
\hline & $(0.10)$ & $(0.27)$ & & & & $(0.10)$ & $(0.22)$ & & \\
\hline \multirow[t]{2}{*}{$\mathrm{P} 5$} & -0.16 & $2.79 * * *$ & 0.33 & & $\mathrm{P} 5$ & 0.08 & $3.96^{* * *}$ & 0.54 & \\
\hline & $(0.11)$ & $(0.26)$ & & & & $(0.12)$ & $(0.22)$ & & \\
\hline $\mathrm{P} 6$ & $\begin{array}{r}-0.02 \\
(0.09)\end{array}$ & $4.23^{* * *}$ & 0.65 & & & & & & \\
\hline \multicolumn{10}{|c|}{ Panel B: Risk Prices } \\
\hline & const & $F$ & RMSE & $R^{2}$ & & const & $F$ & RMSE & $R^{2}$ \\
\hline \multirow[t]{2}{*}{$\lambda$} & -0.15 & $0.14^{* * *}$ & 0.05 & 0.89 & $\lambda$ & 0.00 & $0.09^{* * *}$ & 0.09 & 0.60 \\
\hline & $(0.15)$ & $(0.03)$ & & & & $(0.16)^{*}$ & $(0.03)$ & & \\
\hline$\chi^{2}$ & 7.16 & & & & $\chi^{2}$ & $8.37^{* *}$ & & & \\
\hline$[p$-value $]$ & [0.13] & & & & {$[p$-value $]$} & {$[0.04]$} & & & \\
\hline
\end{tabular}

Notes: This table displays asset pricing results from the Fama and MacBeth (1973) two pass procedure. Panel A: Factor Betas provides time series regressions of excess returns of carry trade portfolios on a constant $(\alpha)$, and the common factor $(F)$ using Equation (1). The standard errors are reported in parentheses and obtained by the Newey and West (1987) procedure with optimal lag selection according to Andrews (1991). The adjusted $R^{2}$ are also reported. Panel B: Risk Prices presents cross-sectional pricing results of the linear factor model. The coefficient of factor risk premium $\lambda$ is estimated using Equation (2). A constant term is employed, instead of the average U.S. dollar risk $(D O L)$. Shanken (1992) standard errors are reported in parentheses $(\cdot)$. The $R^{2}$ is a measure of fit between the sample mean of excess return and the predicted mean return. The RMSE is the root of mean-squared error and is reported in percentage points. The $\chi^{2}$ test statistics of pricing errors are reported and the null hypothesis is that there is no pricing error. $p$-values are reported in square brackets [.]. Asterisk $* * *$, and $* * *$ indicate significance at the $10 \%, 5 \%$ and $1 \%$ level, respectively. The sample period is from November 1983 to December 2013. 


\section{Robustness}

The results in the previous section show that our common factor prices currency portfolios. This section examines the robustness of our empirical results. We have used the two factor model in the previous section, as is standard in the literature. Nevertheless, the average U.S. dollar factor $(D O L)$ may be correlated to the world stock market return, since U.S. dollar based stock market returns have exposure to the base currency. Table 6 shows the results of the asset pricing model using a constant term, instead of the average U.S. dollar factor. This change does not affect the results. Time series betas on the common factor and cross-sectional risk prices are statistically significant at the $1 \%$ level. The adjusted $R^{2} \mathrm{~s}$ imply that the common factor is strongly associated with the high interest rate currency portfolios. This is consistent with the beta sorted portfolio results in Table 5. The impact of risk prices is almost similar to the model that has $D O L$.

Further six robustness results are included in the Online Appendix. We will describe six tests and show that all robustness test results support our common factor. The first robustness test that we consider here relates to the procedure of constructing the mimicking portfolio. We test whether altering this procedure affects the estimation results. We use the common factor $f$ rather than using the mimicking portfolio. Panel A in Table A6 provides empirical evidence that this change does not affect our results. In the second test, we increase the number of test portfolios to examine whether the small number was driving our results. Lewellen et al. (2010) propose to include portfolios sorted by other characteristics in the stock market context, when test portfolios have a factor structure. Following Menkhoff et al. (2012b), momentum portfolios are constructed based on the past one month currency excess returns. For all countries we construct six momentum portfolios, and for developed countries, we use five momentum portfolios. Panel B in Table A6 shows that once the momentum portfolios are included, the common factor remains statistically significant at the $1 \%$ level. 
Third, we adopt a country-level asset pricing model. Lustig et al. (2011) and Ahmed and Valente (2015) argue that the country-level model can deal with the data-snooping biases mentioned by Lo and MacKinlay (1990), and the information problems presented by Ang et al. (2010). ${ }^{8}$ The data snooping bias is more serious when we use a portfolio approach. Further, the portfolio approach may lose substantial information, as shown by Ang et al. (2010). To deal with these possible drawbacks of the portfolio approach, it may be useful to use individual currencies instead. Panel $\mathrm{C}$ in Table A6 shows that the $R^{2}$ becomes smaller than that of the portfolio approach, but the factor is still statistically significant at the $1 \%$ level and the magnitude is similar to the portfolio result. Fourth, we add a global bid-ask spread innovation factor. This factor is used in Menkhoff et al. (2012a) who show that it can price the cross-sectional currency portfolios. Since our common factor is related to the change in the TED spread, as reported in the Online Appendix, other liquidity measures may enhance the explanatory power. Panel D reports the results, and it shows that the effect of including the bid-ask spread innovation factor is marginal. Our fifth robustness test contains the short-run global FX volatility innovation factor. Although Ahmed and Valente (2015) show that the long-run volatility component is substantial for the carry trade asset pricing model, the short-run volatility component may affect the result. However, Panel E shows that the impact of the short-run volatility is small. Finally, we include the change in global FX skewness. As most factors proposed in the previous literature focus on innovation parts, the innovation component of the global FX skewness is employed. The results in Panel F suggest that this factor also does not play an important role.

\footnotetext{
${ }^{8}$ Lo and MacKinlay (1990) present evidence that finding a portfolio construction idea and testing it on the same dataset, leads to a data snooping bias. Ang et al. (2010) provide evidence that a risk premium depends upon the cross-sectional distribution of beta and idiosyncratic volatility. If we use portfolios, we lose some information of the beta distribution.
} 


\section{Conclusion}

The literature presents evidence of a number of risk factors that can explain carry trade returns. But are these currency and non-currency risks complements or substitutes? In particular, are all carry risks sourced from the stock market, or do they originate elsewhere? We investigate these questions by seeking to summarise a range of risk factor information to model currency carry trades. We test whether common information extracted from currency and non-currency risk factors previously explored in the literature better capture risk information to price the time series and the cross-section of currency returns. Our motivation is based upon theoretical and empirical findings in the literature. For example, Lustig et al. (2011) present a theoretical model and show heterogeneous exposure to the world common risk is a main driver for positive currency carry returns. There is empirical evidence in other assets that the common factor approach successfully extracts substantial information (e.g., Ludvigson and Ng, 2009; Engel 2015 et al., 2015; Giglio et al., 2016). The high minus low interest rate currency portfolios factor, $H M L_{F X}$, can price the crosssectional carry returns well, as shown by Lustig et al. (2011). However, this factor uses information extracted from only two portfolios and, hence, the common factor approach may present a better alternative to $H M L_{F X}$.

We find a common factor exists that summarises currency and non-currency information reasonably well. Although downside stock market risk is widely used in the currency carry trade literature, such as by Atanasov and Nitschca (2014), Dobrynskaya (2014), and Lettau et al. (2014), our empirical results suggest that there are risk characteristics of carry portfolios that are not captured by the downside stock market risk. This result implies the currency and stock markets are not completely integrated. In addition, our common factor does not depend upon a specific risk factor. Our approach appears to be more robust against a change in the sample compared to the $H M L_{F X}$ factor. Therefore, it is advantageous to use a much broader range of information when modelling carry trade risks. 


\section{References}

Ahmed, S., and Valente, G. (2015). Understanding the price of volatility risk in carry trades. Journal of Banking and Finance, 57, 118-129.

Andrews, D. (1991). Heteroskedasticity and autocorrelation consistent covariance matrix estimation. Econometrica, 59, 817-858.

Ang, A., Liu, J., and Schwarz, K. (2010). Using stocks or portfolios in tests of factor models. Working paper, Columbia University.

Atanasov, V. and Nitschka, T. (2014). Currency excess returns and global downside market risk. Journal of International Money and Finance, 47, 268-285.

Brunnermeier, M., Nagel, S., and Pedersen, L. (2009). Carry trades and currency crashes. in: D. Acemoglu, K. Rogoff, and M. Woodford. (Eds.), NBER Macroeconomics Annual 2008, National Bureau of Economic Research, Massachusetts Avenue Cambridge, 313 - 347.

Brandt, M. W., Cochrane, J. H., and Santa-Clara, P. (2006). International risk sharing is better than you think, or exchange rates are too smooth. Journal of Monetary Economics, 53, 671-698.

Burnside C. (2011). The cross-section of foreign currency risk premia and consumption growth risk: Comment. American Economic Review, 101, 3456-3476.

Burnside C., Eichenbaum, M., Kleshchelski I., and Rebelo, S. (2011). Do Peso problems explains in the returns to the carry trade? Review of Financial Studies, 24, 853-891.

Christiansen, C., Ranaldo, A., and Söderlind, P. (2011). The time-varying systematic risk of carry trade strategies. Journal of Financial and Quantitative Analysis, 46, 1107-1125.

Copeland, L. and Lu, W. (2016). Dodging the steamroller: Fundamentals versus the carry trade. Journal of International Financial Markets, Institutions and Money, 42, 115-131.

Darvas, Z. (2009). Leveraged carry trade portfolios. Journal of Banking and Finance, 33, 944-957.

Das, S., Kadapakkam, P-R., and Yiuman, T. (2013). Is carry-trade a viable alternative asset class? Journal of International Financial Markets, Institutions and Money, 24, 247-257.

Dobrynskaya, V. (2014). Downside market risk of carry trades. Review of Finance, 18, 1885-1913.

dos Santos, M. B. C., Klotzle, M. C., and Pinto, A. C. F. (2016). Evidence of risk premiums in emerging market carry trade currencies. Journal of International Financial Markets, Institutions and Money, in press. 
Engel, C. (1996). The forward siscount anomaly and the risk premium: A survey of recent evidence Journal of Empirical Finance, 3, 123-192.

Engel, C., Mark, N. C., and West, K. D. (2015). Factor Model Forecasts of Exchange Rates Econometrics Review, 34, 32-55.

Engle, R F. and Lee, G. G. J. (1999). A long-run and short-run component model of stock return volatility. in: R. F. Engle and H. White. (Eds.), Cointegration, Causality, and Forecasting: A Festschrift in Honour of Clive W.J. Granger, Oxford University Press, New York, 381-441.

Fama, E. F. (1984). Forward and spot exchange rate. Journal of Monetary Economics, 14, 319-338.

Fama, E. F. and MacBeth, J. D. (1973). Risk, return, and equilibrium: Empirical tests. Journal of Political Economy, 81, 607-636.

Farhi, E. and Gabaix, X. (2016). Rare disaster and exchange rates Quarterly Journal of Economics, 131, 1-52.

Giglio, S., Kelly, B., and Pruitt, S. (2016). Systemic risk and the macroeconomy: An empirical evaluation. Journal of Financial Economics, 119, 457-471.

Kan, R., Robotti, C., and Shanken J. (2013). Pricing model performance and the two-pass cross-sectional regression methodology. Journal of Finance, 68, 2617-2649.

Lettau, M., Maggiori, M., and Weber, M. (2014). Conditional risk premia in currency markets and other asset classes. Journal of Financial Economics, 114, 197-225.

Lewellen, J., Nagel, S., and Shanken, J. (2010). A skeptical appraisal of asset pricing test. Journal of Financial Economics, 96, 175-194.

Lewis, K. K. (1995). Puzzles in international financial markets. in: G. M. Grossman and K. Rogoff. (Eds.), Handbook of International Economics, vol.3, North Holland, Amsterdam, 1913-1971.

Lo A. W. and MacKinlay, C. A. (1990). Data-snooping biases in tests of financial asset pricing models. Review of Financial Studies, 3, 431-467.

Ludvigson, S. C., and Ng, S. (2009). Macro factors in bond risk premia. Review of Financial Studies, 22, 5027-5067.

Lustig, H., Roussanov, N., and Verdelhan, A. (2011). Common risk factors in currency markets. Review of Financial Studies, 24, 3731-3777.

Lustig, H. and Verdelhan, A. (2007). The cross-section of foreign currency risk premia and consumption growth risk. American Economic Review, 97, 89-117. 
Menkhoff, L., Sarno, L., Schmeling, M. and Schrimpf, A. (2012a). Carry trades and global foreign exchange volatility. Journal of Finance, 67, 681-718.

Menkhoff, L., Sarno, L., Schmeling, M. and Schrimpf, A. (2012b). Currency momentum strategies. Journal of Financial Economics, 106, 660-684.

Newey, W. K. and West, K. D. (1987). A simple, positive semi-definite, heteroskedasticity and autocorrelation consistent covariance matrix. Econometrica, 55, 703-708.

Orlov. (2016). Currency momentum, carry trades, and market liquidity. Journal of Banking and Finance, 67, 1-11.

Rafferty, B. (2011). Currency returns, skewness and crash risk. Working Paper, Duke University.

Shanken, J. (1992). On the estimation of beta-pricing models. Review of Financial Studies, 5, 1-33. 


\section{Common Information in Carry Trade Risk Fac- tors}

Joseph P. Byrne, Boulis Maher Ibrahim, and Ryuta Sakemoto

October 14th 2016

\section{Online Supplement, Not for Publication}

This online material contains more details of our research on carry trades. We show the correlation table across risk factors, data definition and sources, estimated betas on other factors, the comparison result between the common and stock market factors, and other robustness test results.

Table A1 Descriptive Statistics

\begin{tabular}{|c|c|c|c|c|c|c|c|}
\hline & $\mathrm{P} 1$ & $\mathrm{P} 2$ & P3 & $\mathrm{P} 4$ & $\mathrm{P} 5$ & $\mathrm{P} 6$ & $H M L_{F X}$ \\
\hline \multicolumn{8}{|c|}{ Panel A: All countries } \\
\hline \multirow[t]{2}{*}{ Mean } & 0.38 & -0.12 & 1.97 & $3.38^{* *}$ & 2.00 & $5.66^{* * *}$ & $5.29 * * *$ \\
\hline & {$[0.23]$} & {$[-0.08]$} & {$[1.28]$} & {$[2.15]$} & {$[1.12]$} & {$[2.74]$} & {$[3.33]$} \\
\hline Std.dev. & 8.96 & 8.59 & 8.47 & 8.28 & 9.02 & 9.86 & 7.69 \\
\hline Skewness & -0.06 & -0.09 & -0.18 & -0.21 & -0.42 & -0.25 & -0.18 \\
\hline Kurtosis & 3.99 & 4.03 & 3.71 & 4.45 & 4.32 & 4.64 & 4.39 \\
\hline \multicolumn{8}{|c|}{ Panel B: Developed countries } \\
\hline \multirow[t]{2}{*}{ Mean } & 1.21 & 0.04 & 1.55 & $3.27^{*}$ & $5.21^{* *}$ & & $3.98^{* *}$ \\
\hline & {$[0.64]$} & {$[0.02]$} & {$[0.85]$} & {$[1.93]$} & {$[2.50]$} & & {$[2.42]$} \\
\hline Std.dev. & 10.54 & 9.82 & 9.54 & 9.34 & 10.48 & & 8.91 \\
\hline Skewness & -0.06 & -0.09 & -0.18 & -0.21 & -0.42 & & -0.18 \\
\hline Kurtosis & 3.99 & 4.03 & 3.71 & 4.45 & 4.32 & & 4.39 \\
\hline
\end{tabular}

Notes: This table reports annualized mean, annualized standard deviations, skewness, and kurtosis of USD excess returns of currency portfolios sorted monthly at $t-1$ by forward discounts. $H M L_{F X}$ denotes a portfolio that is long in portfolio 6 (5) and short in portfolio 1. Newey and West (1987) HAC $t$-statistics are reported in square brackets [·]. Asterisk *,**, and $* * *$ indicate significance at the $10 \%, 5 \%$ and $1 \%$ levels, respectively. The sample period of all and developed countries is November 1983 to December 2013. 


\section{Table A2 Sources and Definition of Data}

\begin{tabular}{lll}
\hline Series & Definition & Source \\
\hline Spot exchange rate & Spot exchange rate with bid and ask spread & Datastream \\
Forward exchange rate & Forward exchange rate with bid and ask spread & Datastream \\
TED spread & 3 Month or 90 day Rates and Yields: & \\
& Interbank Rates for the United States & \\
& -3 Month Treasury Bill: Secondary Market Rate & FRB St. Louis \\
World stock market & MSCI World total return index (USD) & Datastream \\
Risk free rate & 1 Month Treasury Bill & K. R. French webpage \\
Nondurable consumption $(N D)$ & Personal Consumption Expenditures: & FRB St. Louis \\
& Nondurable Goods & FRB St. Louis \\
Population $(T P)$ & Total Population: All Ages & including Armed Forces Overseas \\
& Consumer Price Index for All Urban Consumers: & FRB St. Louis \\
CPI nondurable $(C P I N D)$ & Nondurables & \\
& $(N D / T P) / C P I N D$. & \\
Real nondurable consumption & $N D / T P$ and $C P I N D$ transformed into indexes & \\
in per capita $(N C)$ & and 1959 January $=100$ & \\
& Personal Consumption Expenditures: & FRB St. Louis \\
Durable consumption $(D)$ & Durable Goods & FRB St. Louis \\
CPI durable $(C P I D)$ & Consumer Price Index for All Urban Consumers: & \\
& Durables & \\
Real durable consumption & $(D / T P) / C P I D$. & \\
in per capita $(C)$ & $D / T P$ and $C P I D$ are transformed into indexes & \\
& and 1959 January =100 & \\
\hline
\end{tabular}

Notes: The table shows the definitions of data series. 


\section{Table A3 Correlation Matrix}

\begin{tabular}{|c|c|c|c|c|c|c|c|c|}
\hline \multicolumn{9}{|c|}{ Panel A: All countries } \\
\hline & $H M L_{F X}$ & $\Delta V O L_{F X}$ & $S K E W_{F X}$ & $\Delta L V O L_{F X}$ & $\triangle T E D$ & $W m k t$ & $D W m k t$ & $N D C G$ \\
\hline$\Delta V O L_{F X}$ & -0.32 & & & & & & & \\
\hline$S K E W_{F X}$ & -0.17 & 0.05 & & & & & & \\
\hline$\Delta L V O L_{F X}$ & -0.17 & -0.80 & 0.04 & & & & & \\
\hline$\triangle T E D$ & -0.13 & 0.15 & 0.05 & 0.23 & & & & \\
\hline$W m k t$ & 0.18 & -0.25 & -0.12 & -0.22 & -0.19 & & & \\
\hline$D W m k t$ & 0.18 & -0.31 & -0.06 & -0.24 & -0.21 & 0.87 & & \\
\hline$\Delta N C$ & -0.04 & 0.02 & 0.11 & 0.07 & 0.00 & 0.12 & 0.14 & \\
\hline$\Delta C$ & 0.04 & 0.02 & -0.01 & 0.07 & -0.09 & 0.03 & 0.09 & 0.20 \\
\hline \multicolumn{9}{|c|}{ Panel B: Developed countries } \\
\hline & $H M L_{F X}$ & $\Delta V O L_{F X}$ & $S K E W_{F X}$ & $\triangle L V O L_{F X}$ & $\triangle T E D$ & $W m k t$ & $D W m k t$ & $N D C G$ \\
\hline$\triangle V O L_{F X}$ & -0.31 & & & & & & & \\
\hline$S K E W_{F X}$ & -0.18 & 0.06 & & & & & & \\
\hline$\Delta L V O L_{F X}$ & -0.19 & -0.78 & 0.06 & & & & & \\
\hline$\triangle T E D$ & -0.17 & 0.14 & 0.05 & 0.29 & & & & \\
\hline$W m k t$ & 0.21 & -0.34 & -0.11 & -0.25 & -0.19 & & & \\
\hline DWmkt & 0.18 & -0.31 & -0.08 & -0.27 & -0.21 & 0.87 & & \\
\hline$\Delta N C$ & 0.00 & 0.01 & 0.12 & 0.07 & 0.00 & 0.12 & 0.14 & \\
\hline$\Delta C$ & 0.03 & 0.04 & -0.01 & 0.07 & -0.09 & 0.03 & 0.09 & 0.20 \\
\hline
\end{tabular}

Notes: The table contains Pearson correlation coefficients for risk factors. $H M L_{F X}$ denotes the return spread between high and low currency portfolios, $\triangle V O L_{F X}$ denotes the global FX volatility innovations, $S K E W_{F X}$ denotes the global FX skewness, $\triangle L V O L_{F X}$ denotes the long-run global FX volatility innovations, $\triangle T E D$ denotes the TED spread innovations, Wmkt denotes the excess return of the world stock market, $D W m k t$ denotes the downside excess return of the world stock market, $\Delta N C$ denotes the U.S. nondurable consumption growth, and $\Delta C$ denotes the U.S. durable consumption growth. The sample period is from November 1983 to December 2013. The bold font indicates significance at the $1 \%$ level. 
Table A4 Factor Betas

\begin{tabular}{|c|c|c|c|c|}
\hline \multicolumn{5}{|c|}{ Panel A: $H M L_{F X}$} \\
\hline Portfolio & $\alpha$ & $D O L$ & $H M L_{F X}$ & $\operatorname{adj}-R^{2}$ \\
\hline \multirow[t]{2}{*}{$\overline{\mathrm{P} 1}$} & 0.04 & $1.02^{* * *}$ & $-0.44^{* * *}$ & 0.92 \\
\hline & $(0.04)$ & $(0.02)$ & $(0.03)$ & \\
\hline \multirow[t]{2}{*}{$\mathrm{P} 2$} & $-0.10^{*}$ & $0.99^{* * *}$ & $-0.22^{* * *}$ & 0.87 \\
\hline & $(0.05)$ & $(0.03)$ & $(0.03)$ & \\
\hline \multirow[t]{2}{*}{ P3 } & 0.01 & $1.00 * * *$ & $-0.06^{* *}$ & 0.90 \\
\hline & $(0.05)$ & $(0.02)$ & $(0.03)$ & \\
\hline \multirow[t]{2}{*}{ P4 } & 0.08 & $0.95^{* * *}$ & $0.07^{* *}$ & 0.86 \\
\hline & $(0.05)$ & $(0.03)$ & $(0.03)$ & \\
\hline \multirow[t]{2}{*}{ P5 } & -0.06 & $1.03^{* * *}$ & $0.08^{* *}$ & 0.85 \\
\hline & $(0.05)$ & $(0.03)$ & $(0.03)$ & \\
\hline \multirow[t]{2}{*}{ P6 } & 0.04 & $1.02^{* * *}$ & $0.56^{* * *}$ & 0.94 \\
\hline & $(0.04)$ & $(0.02)$ & $(0.03)$ & \\
\hline \multicolumn{5}{|c|}{ Panel B: $\triangle V O L_{F X}$} \\
\hline Portfolio & $\alpha$ & $D O L$ & $\Delta V O L_{F X}$ & $\operatorname{adj}-R^{2}$ \\
\hline \multirow[t]{2}{*}{$\mathrm{P} 1$} & $0.05^{*}$ & $1.17^{* * *}$ & $0.32^{* * *}$ & 0.97 \\
\hline & $(0.03)$ & $(0.01)$ & $(0.01)$ & \\
\hline \multirow[t]{2}{*}{ P2 } & $-0.11^{* *}$ & $1.06^{* * *}$ & $0.13^{* * *}$ & 0.87 \\
\hline & $(0.05)$ & $(0.03)$ & $(0.02)$ & \\
\hline \multirow[t]{2}{*}{ P3 } & 0.00 & $1.01^{* * *}$ & $0.03^{*}$ & 0.90 \\
\hline & $(0.05)$ & $(0.02)$ & $(0.02)$ & \\
\hline \multirow[t]{2}{*}{$\mathrm{P} 4$} & 0.04 & $0.89^{* * *}$ & $-0.11^{* * *}$ & 0.88 \\
\hline & $(0.05)$ & $(0.03)$ & $(0.02)$ & \\
\hline \multirow[t]{2}{*}{ P5 } & $-0.09^{*}$ & $0.97^{* * *}$ & $-0.11^{* * *}$ & 0.87 \\
\hline & $(0.05)$ & $(0.03)$ & $(0.02)$ & \\
\hline \multirow[t]{2}{*}{65} & $0.11^{*}$ & $0.90^{* * *}$ & $-0.26^{* * *}$ & 0.85 \\
\hline & $(0.06)$ & $(0.03)$ & $(0.02)$ & \\
\hline \multicolumn{5}{|c|}{ Panel C: $W m k t$} \\
\hline Portfolio & $\alpha$ & $D O L$ & $W m k t$ & $\operatorname{adj}-R^{2}$ \\
\hline \multirow[t]{2}{*}{$\overline{\mathrm{P} 1}$} & -0.06 & $1.36^{* * *}$ & $-0.48^{* * *}$ & 0.82 \\
\hline & $(0.07)$ & $(0.06)$ & $(0.06)$ & \\
\hline \multirow[t]{2}{*}{ P2 } & $-0.09^{*}$ & $1.37^{* * *}$ & $-0.50 * * *$ & 0.88 \\
\hline & $(0.05)$ & $(0.05)$ & $(0.06)$ & \\
\hline \multirow[t]{2}{*}{ P3 } & $0.08^{* *}$ & $1.40^{* * *}$ & $-0.52^{* * *}$ & 0.94 \\
\hline & $(0.04)$ & $(0.04)$ & $(0.04)$ & \\
\hline \multirow[t]{2}{*}{$\mathrm{P} 4$} & 0.01 & $0.55^{* * *}$ & $0.51^{* * *}$ & 0.90 \\
\hline & $(0.04)$ & $(0.06)$ & $(0.07)$ & \\
\hline \multirow[t]{2}{*}{ P5 } & -0.03 & $1.01^{* * *}$ & 0.03 & 0.85 \\
\hline & $(0.06)$ & $(0.07)$ & $(0.06)$ & \\
\hline \multirow[t]{2}{*}{ P6 } & 0.09 & $0.31^{* * *}$ & $0.96^{* * *}$ & 0.86 \\
\hline & $(0.06)$ & $(0.07)$ & (0.09) & \\
\hline
\end{tabular}

Notes: See the next page 
Table A4 Factor Betas (cont.)

\begin{tabular}{|c|c|c|c|c|}
\hline $\begin{array}{l}\text { Panel A } \\
\text { Portfolio }\end{array}$ & $k t_{\alpha}$ & $D O L$ & $D W m k t$ & $\operatorname{adj}-R^{2}$ \\
\hline $\mathrm{P} 1$ & $\begin{array}{r}-0.01 \\
(0.06)\end{array}$ & $1.38^{* * *}$ & $-1.15^{* * *}$ & 0.86 \\
\hline P2 & $\begin{array}{l}(0.06) \\
-0.09^{*} \\
(0.05)\end{array}$ & $\begin{array}{l}(0.04) \\
1.25^{* * *} \\
(0.04)\end{array}$ & $\begin{array}{l}(0.08) \\
-0.79^{* * *} \\
(0.09)\end{array}$ & 0.88 \\
\hline P3 & $\begin{array}{r}0.06 \\
(0.04)\end{array}$ & $\begin{array}{l}1.22^{* * *} \\
(0.03)\end{array}$ & $\begin{array}{l}-0.66^{* * *} \\
(0.08)\end{array}$ & 0.92 \\
\hline P4 & $\begin{array}{r}-0.02 \\
(0.04)\end{array}$ & $\begin{array}{c}0.62^{* * *} \\
(0.04)\end{array}$ & $\begin{array}{l}0.97^{* * *} \\
(0.10)\end{array}$ & 0.92 \\
\hline P5 & $\begin{array}{l}-0.04 \\
(0.05)\end{array}$ & $\begin{array}{l}0.99^{* * * *} \\
(0.05)\end{array}$ & $\begin{array}{r}0.13 \\
(0.11)\end{array}$ & 0.85 \\
\hline $\mathrm{P} 6$ & $\begin{array}{r}0.09 \\
(0.06)\end{array}$ & $\begin{array}{l}0.54^{* * *} \\
(0.06)\end{array}$ & $\begin{array}{l}1.50^{* * *} \\
(0.15)\end{array}$ & 0.85 \\
\hline
\end{tabular}

Notes: This table displays asset pricing results from time series regressions of excess returns of carry trade portfolios on a constant $(\alpha)$, the average U.S. dollar risk $(D O L)$ and the other factors using Equation (1). We use the high minus low currency portfolios $\left(H M L_{F X}\right)$, global FX volatility innovations $\left(\triangle V O L_{F X}\right)$, world stock market excess return $(W m k t)$, and downside world stock market excess return $(D W m k t)$. The test assets are six all country currency portfolios. The standard errors are reported in parentheses $(\cdot)$ and obtained by the Newey and West (1987) procedure with optimal lag selection according to Andrews (1991). The adjusted $R^{2}$ are also reported. Asterisk $* * *$, and *** indicate significance at the $10 \%, 5 \%$ and $1 \%$ levels, respectively. The sample period is from November 1983 to December 2013.

\section{Table A5 Cross-sectional Carry Returns and the orthogonalized Common and Stock Market Factors}

\begin{tabular}{|c|c|c|}
\hline & (1) & (2) \\
\hline$D O L$ & $\begin{array}{r}0.18 \\
(0.12)\end{array}$ & $\begin{array}{r}0.18 \\
(0.12)\end{array}$ \\
\hline$F$ & $\begin{array}{l}0.12^{* * *} \\
(0.03)\end{array}$ & \\
\hline$W m k t^{O r t h}$ & $\begin{array}{l}-0.02 \\
(0.06)\end{array}$ & \\
\hline$W m k t$ & & $\begin{array}{l}0.37^{* * *} \\
(0.11)\end{array}$ \\
\hline$F^{\text {Orth }}$ & & $\begin{array}{l}0.04^{* * *} \\
(0.02)\end{array}$ \\
\hline$R^{2}$ & 0.91 & 0.91 \\
\hline RMSE & 0.05 & 0.05 \\
\hline$\chi^{2}$ & $6.50^{*}$ & $6.50^{*}$ \\
\hline$[p$-value $]$ & {$[0.09]$} & [0.09] \\
\hline
\end{tabular}

Notes: This table presents comparison results between the common factor $F$ and the stock market factor. Orth indicates the factor is orthogonalized with respect to the comparative factor. These cross-section regression results are estimated by Equation (2). Wmkt is the world stock market excess return. Shanken (1992) standard error are reported in parentheses $(\cdot)$. The null hypothesis of the $\chi^{2}$ test is that there are no pricing errors. $p$-values are reported in square brackets [.]. Asterisk $* * *$, and ${ }^{* * *}$ indicate significance at the $10 \%, 5 \%$, and $1 \%$ level, respectively. 
Table A6 Asset pricing: Robustness

Panel A: Non-mimicking portfolio

All countries

\begin{tabular}{lrcccccccc}
\hline & $D O L$ & $f$ & RMSE & $R^{2}$ & & $D O L$ & $f$ & RMSE & $R^{2}$ \\
\hline$\lambda$ & 0.18 & $0.47^{* * *}$ & 0.05 & 0.88 & $\lambda$ & 0.19 & $0.27^{* * *}$ & 0.09 & 0.60 \\
& $(0.12)$ & $(0.12)$ & & & & $(0.13)$ & $(0.10)$ & & \\
$\chi^{2}$ & 6.17 & & & & $\chi^{2}$ & $7.85^{* *}$ & & & \\
{$[p$-value $]$} & {$[0.19]$} & & & & {$[p$-value $]$} & {$[0.05]$} & & & \\
\hline
\end{tabular}

Panel B: Carry and momentum portfolios

All countries

\begin{tabular}{|c|c|c|c|c|c|c|c|c|c|}
\hline & $D O L$ & $F$ & RMSE & $R^{2}$ & & $D O L$ & $F$ & RMSE & $R^{2}$ \\
\hline$\lambda$ & $\begin{array}{r}0.18 \\
(0.12)\end{array}$ & $\begin{array}{c}0.11^{* * *} \\
(0.03)\end{array}$ & 0.10 & 0.45 & $\lambda$ & $\begin{array}{r}0.18 \\
(0.13)\end{array}$ & $\begin{array}{l}0.09^{* * *} \\
(0.03)\end{array}$ & 0.08 & 0.54 \\
\hline $\begin{array}{l}\chi^{2} \\
{[p \text {-value }]}\end{array}$ & $\begin{array}{l}21.39^{* *} \\
{[0.02]}\end{array}$ & & & & $\begin{array}{l}\chi^{2} \\
{[p \text {-value }]}\end{array}$ & $\begin{array}{l}14.05^{*} \\
{[0.08]}\end{array}$ & & & \\
\hline
\end{tabular}

Panel C: Individual currencies

All countries

Developed countries

\begin{tabular}{|c|c|c|c|c|c|c|c|c|c|}
\hline & $D O L$ & $F$ & RMSE & $R^{2}$ & & $D O L$ & $F$ & RMSE & $R^{2}$ \\
\hline$\lambda$ & $\begin{array}{c}0.30^{* *} \\
(0.13)\end{array}$ & $\begin{array}{l}0.12^{* * *} \\
(0.05)\end{array}$ & 1.60 & 0.30 & $\lambda$ & $\begin{array}{c}0.24^{*} \\
(0.14)\end{array}$ & $\begin{array}{c}0.08^{*} \\
(0.04)\end{array}$ & 1.32 & 0.32 \\
\hline
\end{tabular}

Panel D: Including global FX bid-ask spread innovations

All countries

\begin{tabular}{|c|c|c|c|c|c|c|c|c|c|}
\hline & $D O L$ & $F$ & RMSE & $R^{2}$ & & $\overline{D O L}$ & $F$ & RMSE & $R^{2}$ \\
\hline$\lambda$ & $\begin{array}{r}0.18 \\
(0.12)\end{array}$ & $\begin{array}{l}0.12^{* * *} \\
(0.03)\end{array}$ & 0.06 & 0.87 & $\lambda$ & $\begin{array}{r}0.19 \\
(0.13)\end{array}$ & $\begin{array}{l}0.08^{* * *} \\
(0.03)\end{array}$ & 0.09 & 0.60 \\
\hline $\begin{array}{l}\chi^{2} \\
{[p \text {-value }]}\end{array}$ & $\begin{array}{r}7.61 \\
{[0.11]}\end{array}$ & & & & $\begin{array}{l}\chi^{2} \\
{[p \text {-value }]}\end{array}$ & $\begin{array}{c}8.21^{* *} \\
{[0.04]}\end{array}$ & & & \\
\hline
\end{tabular}

Notes: See the next page 


\section{Table A6 Asset pricing: Robustness (cont.)}

\begin{tabular}{|c|c|c|c|c|c|c|c|c|c|}
\hline \multicolumn{10}{|c|}{ Panel E: Including short-run global FX volatility innovations } \\
\hline & $D O L$ & $F$ & RMSE & $R^{2}$ & & $D O L$ & $F$ & RMSE & $R^{2}$ \\
\hline$\lambda$ & $\begin{array}{r}0.18 \\
(0.12)\end{array}$ & $\begin{array}{c}0.12^{* * *} \\
(0.03)\end{array}$ & 0.05 & 0.88 & $\lambda$ & $\begin{array}{r}0.19 \\
(0.13)\end{array}$ & $\begin{array}{c}0.08^{* * *} \\
(0.03)\end{array}$ & 0.09 & 0.60 \\
\hline $\begin{array}{l}\chi^{2} \\
{[p \text {-value }]}\end{array}$ & $\begin{array}{r}7.12 \\
{[0.13]}\end{array}$ & & & & $\begin{array}{l}\chi^{2} \\
{[p \text {-value }]}\end{array}$ & $\begin{array}{l}8.23^{* *} \\
{[0.04]}\end{array}$ & & & \\
\hline \multicolumn{10}{|c|}{ Panel F: Including global FX skewness innovations } \\
\hline & $D O L$ & $F$ & RMSE & $R^{2}$ & & $D O L$ & $F$ & RMSE & $R^{2}$ \\
\hline$\lambda$ & $\begin{array}{r}0.18 \\
(0.12)\end{array}$ & $\begin{array}{l}0.12^{* * *} \\
(0.03)\end{array}$ & 0.05 & 0.88 & $\lambda$ & $\begin{array}{r}0.19 \\
(0.13)\end{array}$ & $\begin{array}{l}0.08^{* * *} \\
(0.03)\end{array}$ & 0.09 & 0.61 \\
\hline $\begin{array}{l}\chi^{2} \\
{[p \text {-value }]}\end{array}$ & $\begin{array}{r}6.84 \\
{[0.14]}\end{array}$ & & & & $\begin{array}{l}\chi^{2} \\
{[p \text {-value }]}\end{array}$ & $\begin{array}{l}8.05^{* *} \\
{[0.05]}\end{array}$ & & & \\
\hline
\end{tabular}

Notes: This table displays cross-sectional pricing results of the linear factor model. The coefficient of factor risk premium $\lambda$ in Equation (2) is estimated by the procedure of Fama and MacBeth (1973). The average U.S. dollar risk $(D O L)$ and the common factors $(F)$ are employed. Panel A uses the common factor $(f)$ directly, not constructing the factor mimicking portfolio. Panel B adopt six (five) carry currency portfolios and six (five) momentum currency portfolios as test assets. Panel C employs individual currency excess returns as test assets. Panel D includes the basic nine risk factors and global FX bid-ask spread innovations, Panel E contains short-run global FX volatility innovations, and Panel F includes global FX skewness innovations. Shanken (1992) standard errors are reported in parentheses $(\cdot)$. The $R^{2}$ is a measure of fit between the sample mean of excess return and the predicted mean return. The RMSE is the root of mean-squared error and is reported in percentage points. The $\chi^{2}$ test statistics of pricing errors are reported and the null hypothesis is that there is no pricing error. $p$-values are reported in square brackets [.]. Asterisk $*{ }^{* *}$, and $* * *$ indicate significance at the $10 \%, 5 \%$ and $1 \%$ level, respectively. The sample period is from November 1983 to December 2013. 